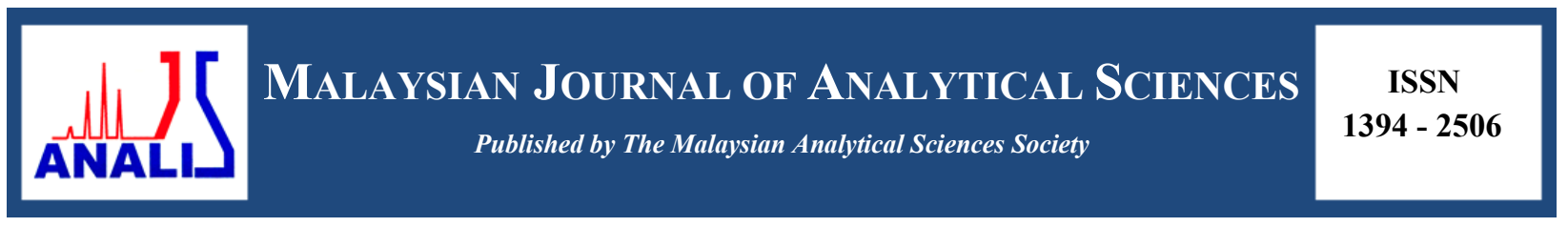

\title{
SOLIDIFIED FLOATING ORGANIC DROP MICROEXTRACTION- ELECTROTHERMAL ATOMIC ABSORPTION SPECTROMETRY FOR THE DETERMINATION OF TRACE AMOUNTS OF LEAD IN WATER SAMPLES
}

\author{
(Pengekstrakan Mikro Pemejalan Titisan Organik Terapung-Spektrometri Serapan Atom \\ Elektrotermal bagi Penentuan Jumlah Surih Plumbum di dalam Sampel Air) \\ Arnon Thongsaw, Ratana Sananmuang, Gareth M. Ross, Wipharat Chuachuad Chaiyasith* \\ Department of Chemistry, \\ Research Center for Academic Excellence in Petroleum, Petrochemical and Advanced Materials, \\ Faculty of Science, \\ Naresuan University, Phitsanulok, Thailand 65000 \\ *Corresponding author: wipharatc@nu.ac.th
}

Received: 14 September 2016; Accepted: 6 December 2016

\begin{abstract}
Solidified floating organic drop microextraction (SFODME) was utilized as a separation or pre-concentration step prior to electrothermal atomic absorption spectrometric (ETAAS) determination of ultra-trace amounts of lead. The method was based on the formation of an extractable complex between $\mathrm{Pb}$ (II) and 1-(2-pyridylazo)-2-naphathol (PAN) as a chelating agent. The main parameters affecting the performance of SFODME, namely, type and volume of organic solvent, $\mathrm{pH}$, concentration of the chelating agent, extraction time, stirring rate, extraction temperature, disperser solvent, ionic strength, and interference effect were investigated and optimized. Under optimized experimental conditions a pre-concentration factor of 22.03 and a detection limit of $0.064 \mu \mathrm{g} \mathrm{L}^{-1}$ for the pre-concentration from $13.0 \mathrm{~mL}$ water sample was achieved. The relative standard deviation of the measurements in the range of $1.3-2.5 \%(n=6)$. The proposed method was assessed through the analysis of certified reference water and recovery experiment with satisfactory results.
\end{abstract}

Keywords: solidified floating organic drop microextraction, lead, electrothermal atomic absorption spectrometry, water samples

\begin{abstract}
Pengekstrakan mikro pemejalan titisan organik terapung (SFODME) digunakan sebagai langkah pemisahan atau pemekatan sebelum penentuan jumlah surih plumbum ditentukan menngunakan spektrometri serapan atom elektrotermal (ETAAS). Kaedah ini berasaskan kepada pembentukkan kompleks yang boleh diekstrak di antara $\mathrm{Pb}$ (II) dan 1-(2p-piridilazo)-2-naphol (PAN) sebagai agen pengkelat. Parameter utama yang memberi kesan kepada prestasi SFODME iaitu jenis dan isipadu pelarut organik, $\mathrm{pH}$, kepekatan agen pengkelat, masa pengekstrakan, kesan pengacauan, suhu pengesktrakan, pelarut serakan, kekuatan ionik dan kesan gangguan telah dikaji dan dioptimumkan. Keadaan optimum bagi eksperimen diperolehi dengan faktor pemekatan pada 22.03 dan had pengesanan dicapai pada $0.064 \mu \mathrm{g} \mathrm{\textrm {L } ^ { - 1 }}$ bagi pemekatan $13.0 \mathrm{~mL}$ sampel air. Pengukuran sisihan piawai relatif berada pada julat $1.3-2.5 \%(n=6)$. Kaedah yang dicadangkan juga dinilai melalui analisis sampel air rujukan yang disahkan dan ujian perolehan semula yang mencapai keputusan memuaskan.
\end{abstract}

Kata kunci: pengekstrakan mikro pemejalan titisan organik terapung, plumbum, spektrometri serapan atom elektrotermal, sampel air 


\section{Introduction}

Nowadays, increasing global environmental pollution is great concern. Heavy metals belong to a class of pollutants that can produce undesirable effects, even if they are present in minuscule amounts. Among the different heavy metals, lead is one of the most common and most toxic pollutants released into the environment from various industrial activities [1]. The accumulation of heavy metals in adults, is associated with heart disease, cancer, and may cause many serious disorders like anemia, kidney diseases, nervous disorder, and even death [2].

The important sources of lead are industrial processes such as smelting of lead, recycling of lead batteries, manufacturing of lead paints, etc. [3], and automobile exhausts. Water quality has become an issue of vital importance as it is an essential resource that is threatened by pollution. Maximum allowable limit of total $\mathrm{Pb}$ in drinking water considered safe by the United States Environmental Protection Agency (EPA) and Ministry of public health, Thailand is $10 \mu \mathrm{g} \mathrm{L}^{-1}$ [4]. The tap water intended for human consumption is controlled regularly for an extensive array of potential contaminants by certified authorities.

Modern instrumental methods including spectrometry, namely, inductively coupled plasma mass spectrometry, inductively coupled plasma atomic emission spectrometry, and atomic absorption spectrometry, etc. [5-7] have been used for the determination of traces of metal ions in various media. However, because of the low concentration of $\mathrm{Pb}$ and the complexity of the environmental samples, direct analysis using the instruments is often impeded by matrix interferences. Several methods have been proposed for separation and pre-concentration of trace $\mathrm{Pb}$, such as, liquid-liquid extraction (LLE) [8, 9], solid-phase extraction (SPE) [10-12], coprecipitation [13], cloud point extraction (CPE) [14, 15], and ion exchange [16]. Although these are the most commonly used sample pre-treatment methods, they have some drawbacks such as large consumption of reagents, low enrichment factors, multistage operation, and lengthy separation.

The miniaturized pre-concentration method based on LLE including, single drop microextraction (SDME) [17], hollow fiber liquid phase microextraction (HF-LPME) [18], homogeneous liquid-liquid extraction [19], and dispersive liquid-liquid microextraction (DLLME) [20, 21]. Solidified floating organic drop microextraction (SFODME) was introduced as one of these by Khalili Zanjini et al. [22]. In this method, a small volume of an organic solvent with a melting point near room temperature (in the range of $10-30{ }^{\circ} \mathrm{C}$ ), which is immiscible with water, is delivered to the surface of an aqueous sample containing the analytes. When the equilibrium is reached, the sample vial is placed in an ice bath to solidify the microdrop which is easily removed and allowed to melt for the quantification of analytes [23].

In the present work, trace analysis of lead was developed based on SFODME technique and determination by electrothermal atomic absorption spectrometry (ETASS). 1-(2-pyridylazo)-2-naphthol (PAN), a chelating reagent widely used for many metals and that permits the pre-concentration of trace metals from solution [24], is used to extract $\mathrm{Pb}$ into the organic phase. This method was applied for the determination of lead in mineral bottled and tap water samples.

\section{Instrumentation}

\section{Materials and Methods}

The experiments were performed with a Varian Model SpectrAA 220Z atomic absorption spectrometer equipped with Zeeman background correction. A lead hollow cathode lamp was used as the radiation source. The analytical wavelength $(283.3 \mathrm{~nm})$, spectral bandwidth $(0.5 \mathrm{~nm})$ and lamp current $(10.0 \mathrm{~mA})$ were used as recommended by manufacturer. The graphite furnace temperature program was optimized and are showed in Table 1. The $\mathrm{pH}$ measurements were carried out with a Metrohm $\mathrm{pH}$ meter model $827 \mathrm{pH}$ lab equipped with a combined glass electrode.

\section{Reagents and solutions}

All reagents used in this study were of analytical grade. The stock solution of $\mathrm{Pb}(\mathrm{II})$ was obtained from AVS Titrinorm (VWR inter-national, Belgium). Working standard solutions were prepared daily by appropriate dilution from the stock solution with deionized water. The stock solutions of the chelating agent, 1-(2-pyridylazo)-2- 
naphthol; PAN, (Acros organics, USA) were prepared by dissolving appropriate amounts in ethanol (ITALMAR, Thailand). The extraction solvent, 1-undecanol, was purchased from Merck, Germany. Buffer solutions of

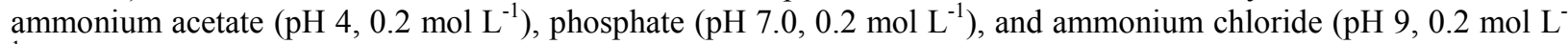
${ }^{1}$ ) were used to adjust the $\mathrm{pH}$ in the range of $2.0-12.0$. The laboratory glassware was kept overnight in a $10 \% \mathrm{HNO}_{3}$ solution. The glassware was washed with deionized water and dried prior to use.

Table 1. Temperature program of ETAAS for determination of $\mathrm{Pb}$

\begin{tabular}{lccc}
\hline Step & $\begin{array}{c}\text { Temperature } \\
\left({ }^{\circ} \mathbf{C}\right)\end{array}$ & $\begin{array}{c}\text { Time } \\
(\mathbf{s})\end{array}$ & $\begin{array}{c}\text { Argon flow rate } \\
(\mathbf{L} / \mathbf{m i n})\end{array}$ \\
\hline 1 & 95 & 15.0 & 0.3 \\
2 & 120 & 5.0 & 0.3 \\
3 & 400 & 14.0 & 0.3 \\
4 & 2100 & 2.9 & 0 \\
5 & 2100 & 2.0 & 0.3 \\
\hline
\end{tabular}

\section{Extraction procedure}

An amount of $13 \mathrm{~mL}$ aliquot, either $15 \mu \mathrm{g} \mathrm{L}^{-1}$ standard or water sample, was placed in a $15-\mathrm{mL}$ screw cap glass vial with flat bottom containing a magnetic stirrer bar. The $\mathrm{pH}$ of the solution was adjusted to 6 using phosphate buffer and $0.5 \mathrm{~mL}$ of a solution of PAN chelating agent $\left(3.0 \mathrm{mmol} \mathrm{L}^{-1}\right)$ was added. After the solution was mixed thoroughly, $90 \mu \mathrm{L}$ of 1-undecanol was spiked into the stirring solution and was mixed for $20 \mathrm{~min}$ at $625 \mathrm{rpm}$, after that, the vial was cooled in an ice bath. The solidified drop of 1-undecanol was obtained rapidly. The solidified solvent was transferred into a vial and where it melted immediately. Therefore, the extract was diluted with ethanol $(500 \mu \mathrm{L})$ and $\mathrm{Pb}(\mathrm{II})$ concentration was determined by electrothermal atomic absorption spectrometer.

\section{Water samples}

In order to validate the method, various water samples, including tap and mineral bottled water (Phitsanulok, Thailand) were selected. A water samples were filtered through a $0.45 \mu \mathrm{m}$ Whatman filter membrane to remove any suspended material prior to the analysis.

\section{Optimization of extraction conditions}

\section{Results and Discussion}

In order to obtain high pre-concentration factor (PF) [25] and good extraction recovery (ER), the effect of different parameters that affect extraction conditions such as type and volume of extraction solvent, $\mathrm{pH}$, amount of chelating agent, stirring rate, extraction time and extraction temperature were optimized.

\section{Effect of type and volume of the extraction solvent}

To obtain optimal results, an appropriate extraction solvent must be chosen. It should have low volatility, density lower than water, low toxicity, and a melting point near room temperature $\left(10-30{ }^{\circ} \mathrm{C}\right)$. In this paper, 1-undecanol (m.p. $13-15{ }^{\circ} \mathrm{C}$ ) and 1-dodecanol (m.p. 22-24 ${ }^{\circ} \mathrm{C}$ ), were used for the initial investigation. When the extraction was done, the analytical absorbances were about 0.071 and 0.034 , respectively. Therefore, 1-undecanol was selected as the extraction solvent for further experiment in this study.

To evaluate the effect of the extraction solvent volume, different volumes of 1-undecanol were added in the range of $20-150 \mu \mathrm{L}$. The results of this experiment are shown in Figure 1. It can be seen that relative absorbance increased with increasing 1-undecanol volume in the range of $20-90 \mu \mathrm{L}$, and then decreased with further volume increases. Therefore, $90 \mu \mathrm{L}$ was chosen as the optimum volume of the extraction solvent for further experiments. After the extraction procedure, the obtained of PF was 22.03. 
Thongsaw et al: SOLIDIFIED FLOATING ORGANIC DROP MICROEXTRACTION-

ELECTROTHERMAL ATOMIC ABSORPTION SPECTROMETRY FOR THE

DETERMINATION OF TRACE AMOUNTS OF LEAD IN WATER SAMPLES

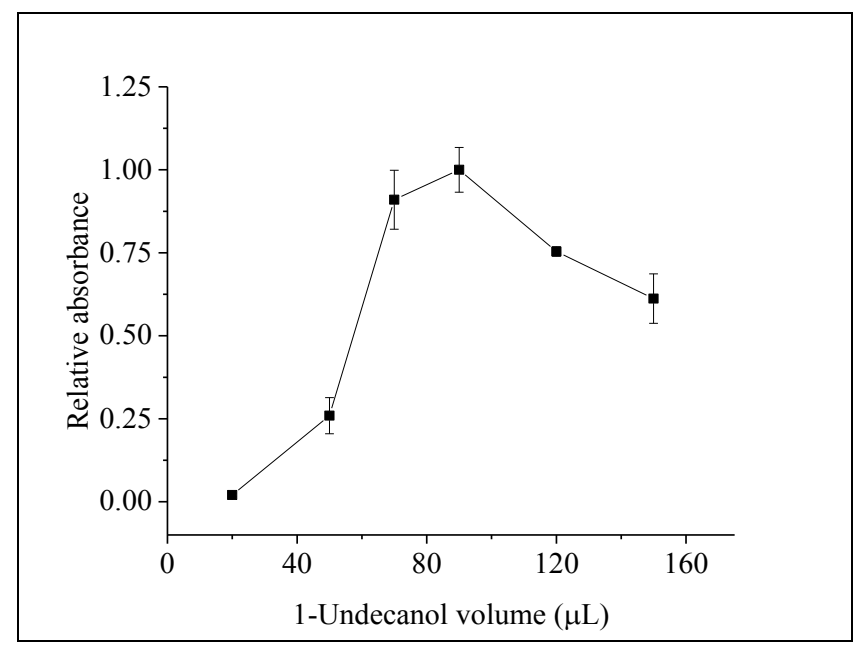

Figure 1. Effect of 1-undecanol volume on the extraction efficiency of lead. Utilized conditions: concentration of $\mathrm{Pb}(\mathrm{II}), 15 \mu \mathrm{g} \mathrm{L}^{-1}$; aqueous volume, $13 \mathrm{~mL}$; $\mathrm{pH} \mathrm{6}$; chelating agent, PAN, $3.0 \mathrm{mmol} \mathrm{L} \mathrm{L}^{-1}, 0.5 \mathrm{~mL}$; extraction time, $3 \mathrm{~min}$; stirring rate, $625 \mathrm{rpm}$; room temperature

\section{Effect of the sample pH}

The $\mathrm{pH}$ of the sample has an effect on metal complex formation. Furthermore, $\mathrm{pH}$ also has influences toward the extraction efficiency of $\mathrm{Pb}$ (II). Therefore, the effect of $\mathrm{pH}$ on the procedure was investigated in the range of 3.012.0. As shown in Figure 2, an absorbance maximum was observed $\mathrm{pH}$ equal to 9.0. Accordingly, a $\mathrm{pH} 9$, obtained with ammonium chloride buffer, was selected for the optimization studies and real sample analysis.

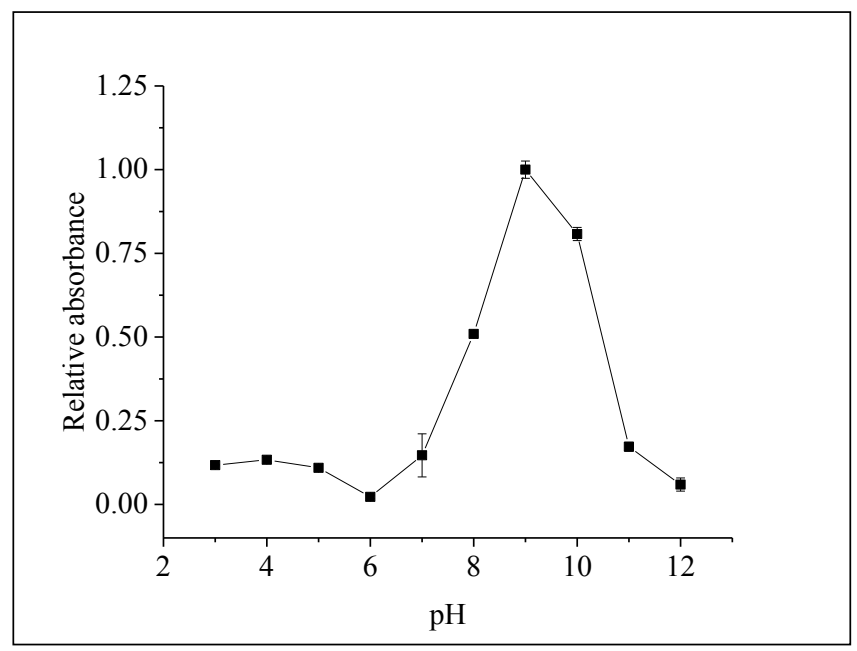

Figure 2. Effect of $\mathrm{pH}$ on the extraction efficiency of lead. Conditions are the same as in Figure 1 except $\mathrm{pH}$, and 1-undecanol volume, $90 \mu \mathrm{L}$

\section{Effect of the PAN concentration}

The effect of PAN concentration, as chelating reagent, on the extraction efficiency was studied using various amounts of ligand ranging from 0.1 to $10.0 \mathrm{mmol} \mathrm{L}^{-1}$ (equal 0.0038 to $0.38 \mathrm{mmol} \mathrm{L}^{-1}$ in final volume of sample, 13 
$\mathrm{mL}$ ). The absorbance was stable when the concentration of ligand was higher than $3.0 \mathrm{mmol} \mathrm{L}^{-1}$, indicating the complete complexation. Therefore, $3.0 \mathrm{mmol} \mathrm{L}^{-1}$ (equal $0.115 \mathrm{mmol} \mathrm{L}^{-1}$ in final solution) was chosen as the optimum concentration for the lead extraction.

\section{Extraction time}

Another important factor that affects the extraction is the extraction time, because of the mass transfer phenomena governing the extraction efficiency of the analyte in SFODME. The effect of the extraction time was studied by varying it in the range of $10-120$ min under constant experimental conditions. The results are shown in Figure 3 . It was found that with increasing extraction time, up to $40 \mathrm{~min}$, the analytical signal increased, and remained constant at a longer extraction times. Thus, 40-min extraction was chosen as the optimum extraction time.

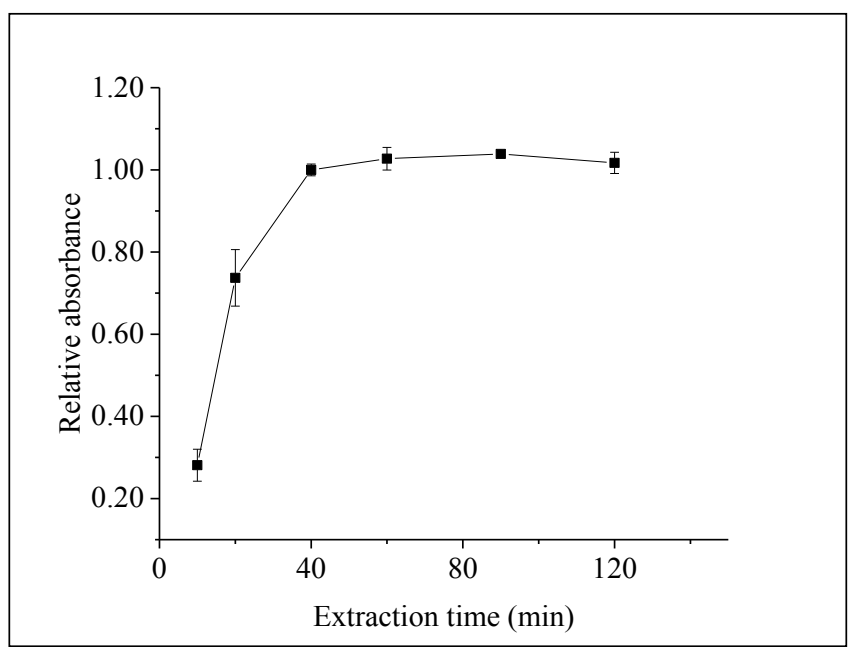

Figure 3. Effect of extraction time on the extraction efficiency of lead. Conditions are the same as in Figure 2 except extraction time. Performed at $\mathrm{pH} 9$

\section{Stirring rate}

To enhance the extraction efficiency, sample stirring during the extraction procedure was applied. Based on the film theory of convective-diffusive mass transfer, increasing the stirring rate can decreased the thickness of the dilution film in the aqueous phase, so the mass-transfer will be increased. The effect of stirring rate on extraction efficiency was studied in the range of $100-1,200 \mathrm{rpm}$. The experimental results show that the analytical signal increases rapidly with increasing stirring rate from 375 to $750 \mathrm{rpm}$, and then remains constant upon further increases up to $1200 \mathrm{rpm}$. Therefore, a stirring rate of $750 \mathrm{rpm}$ was employed for analysis.

\section{Extraction temperature}

Temperature affects the solubility of the organic solvent in water as well as the emulsification and therefore influences the extraction efficiency. This effect was performed by varying the extraction temperature between $20{ }^{\circ} \mathrm{C}$ and $80{ }^{\circ} \mathrm{C}$. The results in Figure 4 showed that the relative absorbance increases with increasing extraction temperature up to $50{ }^{\circ} \mathrm{C}$. At temperatures higher than $50{ }^{\circ} \mathrm{C}$, 1-undecanol was slightly dissolved into the aqueous sample, affecting the analytical signal. Consequently, the extraction temperature at $50{ }^{\circ} \mathrm{C}$ was chosen for further study.

\section{Effect of salts}

The influence of ionic strength on the SFODME method was investigated by adding various amounts of sodium chloride $(\mathrm{NaCl})$ and potassium chloride $(\mathrm{KCl})$ in the range $0-5.0 \%(\mathrm{~m} / \mathrm{v})$ to the sample. The obtained results indicate that increasing the salt concentration from $0 \%$ to $5.0 \%$ does not significantly increase the extraction efficiency. Therefore, salts were not added to the aqueous samples studied in this work. 
Thongsaw et al: SOLIDIFIED FLOATING ORGANIC DROP MICROEXTRACTION-

ELECTROTHERMAL ATOMIC ABSORPTION SPECTROMETRY FOR THE

DETERMINATION OF TRACE AMOUNTS OF LEAD IN WATER SAMPLES

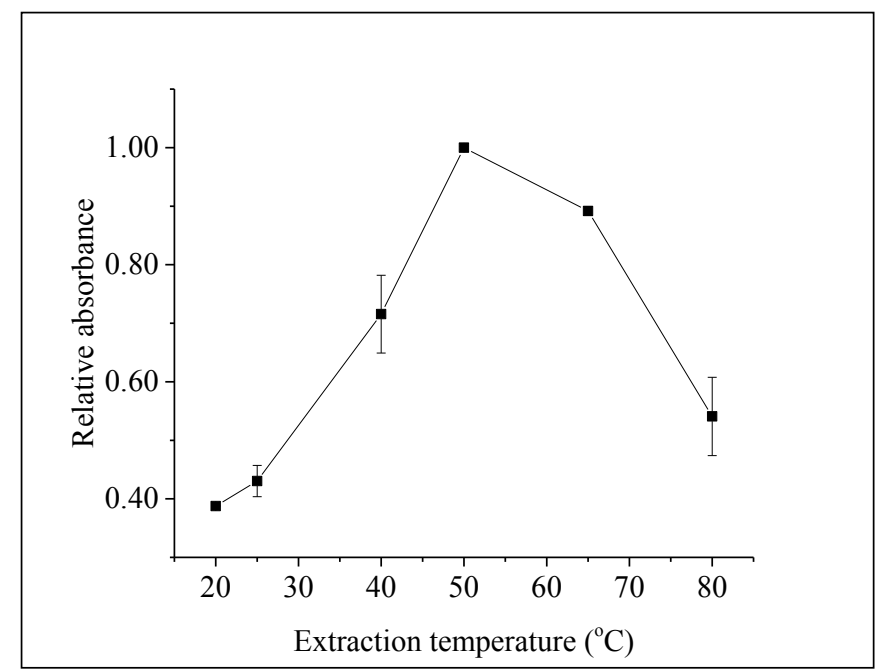

Figure 4. Effect of extraction temperature on the extraction efficiency of lead. Conditions are the same as in Figure 3 except extraction temperature. Performed with extraction time of $40 \mathrm{~min}$

A summary of optimal conditions obtained for the SFODME method for pre-concentration and determination of lead is illustrated in Table 2.

Table 2. Optimal conditions for SFODME of lead ions

\begin{tabular}{ll}
\hline Optimal Conditions for SFODME of Pb(II) & \\
\hline Extraction solvent & 1 -undecanol \\
Diluent & ethanol \\
pH & 9 \\
PAN concentration $\left(\mathrm{mmol} \mathrm{L}^{-1}\right)$ & 3.0 \\
Extraction time (min) & 40 \\
Stirring rate (rpm) & 750 \\
Sample volume (mL) & 13 \\
Extraction phase volume $(\mathrm{mL})$ & 0.090 \\
Extraction temperature $\left({ }^{\circ} \mathrm{C}\right)$ & 50 \\
\hline
\end{tabular}

\section{Interference study}

The selectivity of the proposed method in the extraction and determination of the analyte was investigated as well. In these experiments, solutions of $10 \mu \mathrm{g} \mathrm{L}^{-1}$ of $\mathrm{Pb}$ (II) containing interfering ions were treated using the optimized procedure. The tolerance limit was set as the amount of ion required to cause an error of $\pm 5 \%$ in the determination of lead. The maximum tolerance limits of the investigated cations and anions are given in Table 3 . The extraction by SFODME method is based on the fact that the target ions can form hydrophobic metal-PAN complex and them can be extracted to the extraction solvent (1-undecanol). Nonetheless, the tolerance limits of $\mathrm{Mg}^{2+}$ and $\mathrm{Fe}^{3+}$ were not as high as other ions, the concentration of $\mathrm{Mg}^{2+}$ and $\mathrm{Fe}^{3+}$ were at trace levels in several water samples. Therefore, these results indicate that the developed method can be applied to analysis of $\mathrm{Pb}$ in various water samples. 
Table 3. Tolerance limits of interfering ions in the determination of $10 \mu \mathrm{g} \mathrm{L}^{-1} \mathrm{~Pb}$ (II)

\begin{tabular}{lcc}
\hline Ions & $\begin{array}{c}\text { Interfering Ratio } \\
(\mathbf{i o n} / \mathbf{P b})\end{array}$ & $\begin{array}{c}\text { Pb(II) Recovery } \\
(\% \pm \mathbf{S D})\end{array}$ \\
\hline $\mathrm{Na}^{+}$ & 1000 & $103.0 \pm 0.1$ \\
$\mathrm{~K}^{+}$ & 1000 & $94.9 \pm 0.2$ \\
$\mathrm{Cd}^{2+}$ & 100 & $94.2 \pm 0.3$ \\
$\mathrm{Cr}^{3+}$ & 1000 & $97.9 \pm 0.1$ \\
$\mathrm{As}^{3+}$ & 100 & $92.4 \pm 0.1$ \\
$\mathrm{NO}_{3}{ }^{-}$ & 100 & $101.8 \pm 0.1$ \\
$\mathrm{SO}_{4}{ }^{2-}$ & 100 & $100.5 \pm 0.2$ \\
$\mathrm{PO}_{4}{ }^{3-}$ & 100 & $102.5 \pm 0.1$ \\
\hline
\end{tabular}

\section{Analytical performance}

The analytical characteristics such as the linear range, precision, detection limit, and pre-concentration factor were obtained by processing standard solution of $\mathrm{Pb}$. The calibration curve was obtained using the optimized conditions for the SFODME procedure followed by lead concentration determination by ETAAS. Linearity was obtained with lead concentration in the range up to $30.0 \mu \mathrm{g} \mathrm{L}{ }^{-1}$. The regression equation for lead determination is express as below

$$
\mathrm{A}=0.0131 \mathrm{C}+0.0100
$$

where $\mathrm{A}$ is the absorbance and $\mathrm{C}$ is the lead concentration in solution $\left(\mu \mathrm{g} \mathrm{L}^{-1}\right)$. The correlation coefficient of the calibration curve equation was higher than 0.99 . The pre-concentration factor was calculated as the ratio of the volume of the sample prior pre-concentration divided by the volume after pre-concentration. It was found to have a value of 22.03. The LOD and LOQ defined as $3 \mathrm{~S}_{\mathrm{b}} / m$ and $10 \mathrm{~S}_{\mathrm{b}} / m$ (where $\mathrm{S}_{\mathrm{b}}$ is standard deviation of the blank and $m$ is the slope of the calibration graph) were found to be 0.064 and $0.214 \mu \mathrm{g} / \mathrm{L}$, respectively. The relative standard deviation (\%RSD) for 6 replicate determinations at $15 \mu \mathrm{g} \mathrm{L}{ }^{-1}$ of $\mathrm{Pb}(\mathrm{II})$ is $\pm 2.5 \%$.

\section{Sample analysis}

To examine the reliability of this procedure, the method was applied for the determination of lead in mineral bottled and tap water samples. The accuracy of the proposed method was verified by spiking experiments at two concentration levels. As tabulated in Table 4, the recoveries of the added lead were always higher than $91 \%$. To verify the accuracy of the proposed procedure, the method was used for the determination of lead in a sample of NRC-CNRC, National Research Council of Canada (SLRS-4). The results of this test are presented in Table 4, good agreement between the determined and certified values was obtained. Furthermore, these results indicate that the matrices of the mineral bottled and tap water samples had little effect on the SFODME-ETAAS method for the determination of lead. Comparison of pre-concentration techniques used for lead determination with ETAAS was showed in Table 5.

Table 4. Determination of lead(II) in several water samples. $(\mathrm{n}=2)$

\begin{tabular}{|c|c|c|c|c|}
\hline Sample & $\begin{array}{c}\text { Certified } \\
\left(\mu \mathrm{g} \mathrm{L}^{-1}\right)\end{array}$ & $\begin{array}{c}\text { Added } \\
\left(\mu \mathrm{g} \mathrm{L}^{-1}\right)\end{array}$ & $\begin{array}{l}\text { Found } \\
\left(\mu \mathrm{g} \mathrm{L}^{-1}\right)\end{array}$ & $\begin{array}{c}\text { Recovery } \\
(\%)\end{array}$ \\
\hline $\begin{array}{l}\text { SLRS-4 } \\
\text { (River water) }\end{array}$ & $0.086 \pm 0.007$ & - & $0.090 \pm 0.019$ & $105.0 \pm 1.9$ \\
\hline Drinking water1 & & $\begin{array}{c}0.0 \\
5.0 \\
15.0\end{array}$ & $\begin{array}{c}0.7 \pm 0.2 \\
5.6 \pm 0.1 \\
15.3 \pm 0.1\end{array}$ & $\begin{array}{c}- \\
97.0 \pm 0.1 \\
97.6 \pm 2.5\end{array}$ \\
\hline
\end{tabular}


Thongsaw et al: SOLIDIFIED FLOATING ORGANIC DROP MICROEXTRACTION-

ELECTROTHERMAL ATOMIC ABSORPTION SPECTROMETRY FOR THE

DETERMINATION OF TRACE AMOUNTS OF LEAD IN WATER SAMPLES

Table 4 (cont'd). Determination of lead(II) in several water samples. $(\mathrm{n}=2)$

\begin{tabular}{|c|c|c|c|c|}
\hline Sample & $\begin{array}{c}\text { Certified } \\
\left(\mu \mathrm{g} \mathrm{L}^{-1}\right)\end{array}$ & $\begin{array}{c}\text { Added } \\
\left(\mu g L^{-1}\right)\end{array}$ & $\begin{array}{l}\text { Found } \\
\left(\mu \mathrm{g} \mathrm{L}^{-1}\right)\end{array}$ & $\begin{array}{c}\text { Recovery } \\
(\%)\end{array}$ \\
\hline Drinking water 2 & & $\begin{array}{c}0.0 \\
5.0 \\
15.0\end{array}$ & $\begin{array}{c}\text { ND* } \\
4.7 \pm 0.1 \\
15.3 \pm 0.2\end{array}$ & $\begin{array}{c}- \\
94.8 \pm 1.3 \\
102.1 \pm 1.9\end{array}$ \\
\hline Drinking water 3 & & $\begin{array}{c}0.0 \\
5.0 \\
15.0\end{array}$ & $\begin{array}{c}\mathrm{ND}^{*} \\
5.2 \pm 0.3 \\
12.4 \pm 0.2\end{array}$ & $\begin{array}{c}- \\
103.7 \pm 1.3 \\
82.7 \pm 5.7\end{array}$ \\
\hline Drinking water 4 & & $\begin{array}{c}0.0 \\
5.0 \\
15.0\end{array}$ & $\begin{array}{c}1.56 \pm 0.3 \\
6.8 \pm 0.2 \\
16.9 \pm 0.3\end{array}$ & $\begin{array}{c}- \\
105.9 \pm 1.9 \\
102.2 \pm 3.6\end{array}$ \\
\hline Drinking water 5 & & $\begin{array}{c}0.0 \\
5.0 \\
15.0\end{array}$ & $\begin{array}{c}1.8 \pm 0.1 \\
6.8 \pm 0.1 \\
15.2 \pm 0.2\end{array}$ & $\begin{array}{c}- \\
101.0 \pm 1.4 \\
89.4 \pm 2.5\end{array}$ \\
\hline Tap water 1 & & $\begin{array}{c}0.0 \\
10.0 \\
20.0\end{array}$ & $\begin{array}{c}\mathrm{ND}^{*} \\
10.2 \pm 0.2 \\
21.5 \pm 0.5\end{array}$ & $\begin{array}{c}- \\
101.1 \pm 2.3 \\
107.4 \pm 2.4\end{array}$ \\
\hline Tap water 2 & & $\begin{array}{c}0.0 \\
10.0 \\
20.0\end{array}$ & $\begin{array}{c}1.9 \pm 0.1 \\
12.0 \pm 0.4 \\
21.6 \pm 0.4\end{array}$ & $\begin{array}{c}- \\
100.6 \pm 1.9 \\
98.1 \pm 4.4\end{array}$ \\
\hline Tap water 3 & & $\begin{array}{c}0.0 \\
10.0 \\
20.0\end{array}$ & $\begin{array}{c}2.9 \pm 0.2 \\
12.0 \pm 0.4 \\
21.6 \pm 0.4\end{array}$ & $\begin{array}{c}- \\
91.5 \pm 1.9 \\
93.6 \pm 4.0\end{array}$ \\
\hline Tap water 4 & & $\begin{array}{c}0.0 \\
10.0 \\
20.0\end{array}$ & $\begin{array}{c}0.3 \pm 0.1 \\
10.5 \pm 0.1 \\
20.2 \pm 0.4\end{array}$ & $\begin{array}{c}- \\
102.5 \pm 1.2 \\
99.6 \pm 1.8\end{array}$ \\
\hline Tap water 5 & & $\begin{array}{c}0.0 \\
10.0 \\
20.0\end{array}$ & $\begin{array}{c}1.3 \pm 0.3 \\
12.0 \pm 0.2 \\
21.0 \pm 0.2\end{array}$ & $\begin{array}{c}- \\
107.1 \pm 0.9 \\
98.8 \pm 1.7\end{array}$ \\
\hline
\end{tabular}

*N.D.: Not detected

Table 5. Comparison of pre-concentration techniques used for lead determination with ETAAS

\begin{tabular}{|c|c|c|c|c|c|c|c|}
\hline $\begin{array}{l}\text { Analytical } \\
\text { Technique }\end{array}$ & $\begin{array}{l}\text { Chelating } \\
\text { Reagent }\end{array}$ & $\begin{array}{c}\text { Sample } \\
\text { Volume }(\mathrm{mL})\end{array}$ & $\begin{array}{c}\text { Linear } \\
\text { Range } \\
\left(\mu \mathrm{g} \mathrm{L}^{-1}\right)\end{array}$ & $\underset{\left(\mu \mathrm{g} \mathrm{L}^{-1}\right)}{\text { LOD }}$ & $\%$ RSD & PF & Reference \\
\hline Batch-CPE & 5-Br-PADAP & 10.0 & Up to 30.0 & 0.08 & 2.8 & 50 & [26] \\
\hline Batch-DLLME & DDTP & 5.0 & $0.05-1.0$ & 0.02 & 2.5 & 150 & [27] \\
\hline On-line-SPE & PSTH-cpg & 3.3 & $0.1-10.0$ & 0.012 & 3.2 & 20.5 & [12] \\
\hline SFODME & PAN & 13.0 & $0.0-30.0$ & 0.064 & 2.48 & 22.03 & This work \\
\hline
\end{tabular}

PF: pre-concentration factor 


\section{Conclusion}

It has been shown that solidified floating organic drop microextraction (SFODME) combined with ETAAS, can be used for the separation or pre-concentration of ultra-trace amount of lead in mineral bottled and tap water samples. A comparison of the represented method with the other liquid-liquid microextraction methods using different detection techniques for lead extraction and determination was successfully identified. It can be seen that the working range of SFODME-ETAAS is wider than that of the other reported methods. The main advantages of this methodology are simplicity, low cost, high enrichment factor, rejection of matrix constituents, and minimum use of organic solvents. Additional studies are in progress to evaluate the parameters of the SFODME method for preconcentration and determination of other metals using various ligands and complexing agents in different matrices.

\section{Acknowledgements}

The authors acknowledge the financial support from Science Achievement Scholarship of Thailand and Research Center for Academic Excellence in Petroleum, Petrochemical and Advanced Materials, Faculty of science, Naresuan University, Thailand. We are grateful to Dr. Filip Kielar for his kind assistance on English editing.

\section{References}

1. Yurtsever, M. and Şengil, İ. A. (2009). Biosorption of Pb(II) ions by modified quebracho tannin resin. Journal of Hazardous Materials, 163: 58 - 64.

2. Afridi, H. I., Kazi, T. G., Kazi, G. H., Jamali, M. K. and Shar, G. Q. (2006). Essential trace and toxic element distribution in the scalp hair of Pakistani myocardial infarction patients and controls. Biological Trace Element Research, 113: $19-34$.

3. Jusko, T. A., Henderson Jr, C. R., Lanphear, B. P., Cory-Slechta, D. A., Parsons, P. J. and Canfield, R. L. (2008). Blood lead concentrations $<10 \mu \mathrm{g} / \mathrm{dL}$ and child intelligence at 6 years of age. Environmental Health Perspectives, 116: $243-248$.

4. Drinking water contaminants: Standards and Regulations, EPA (2016). Access online from http://water.epa.gov/drink/contaminants /index.cfm). Accessed date 06.09.16.

5. Jitaru, P. and Adams, F. C. (2004). Speciation analysis of mercury by solid-phase microextraction and multicapillary gas chromatography hyphenated to inductively coupled plasma-time-of-flight-mass spectrometry. Journal of Chromatography A, 1055: 197 - 207.

6. Oleszczuk, N., Castro, J. T., da Silva, M. M., Maria das Graças, A. K., Welz, B., and Vale, M. G. R. (2007). Method development for the determination of manganese, cobalt and copper in green coffee comparing direct solid sampling electrothermal atomic absorption spectrometry and inductively coupled plasma optical emission spectrometry. Talanta, 73: $862-869$.

7. Mierzwa, J., Sun, Y. C., and Yang, M. H. (1997). Determination of Co and Ni in soils and river sediments by electrothermal atomic absorption spectrometry with slurry sampling. Analytica Chimica Acta, 355: 277 - 282.

8. Wang, J. and Hansen, E. H. (2002). FI/SI on-line solvent extraction/back extraction pre-concentration coupled to direct injection nebulization inductively coupled plasma mass spectrometry for determination of copper and lead. Journal of Analytical Atomic Spectrometry, 17: 1284 - 1289.

9. Ndung'u, K., Franks, R. P., Bruland, K. W., and Flegal, A. R. (2003). Organic complexation and total dissolved trace metal analysis in estuarine waters: comparison of solvent-extraction graphite furnace atomic absorption spectrometric and chelating resin flow injection inductively coupled plasma-mass spectrometric analysis. Analytica Chimica Acta, 481: 127 - 138.

10. Ghaedi, M., Montazerozohori, M. and Soylak, M. (2007). Solid phase extraction method for selective determination of $\mathrm{Pb}(\mathrm{II})$ in water samples using 4-(4-methoxybenzylidenimine) thiophenole. Journal of Hazardous Materials, 142: 368 - 373.

11. Dadfarnia, S., Talebi, M., Shabani, A. M. H. and Beni, Z. (2007). Determination of lead and cadmium in different samples by flow injection atomic absorption spectrometry incorporating a microcolumn of immobilized ammonium pyrrolidine dithiocarbamate on microcrystalline naphthalene. Croatian Chemica Acta, 80: $17-23$.

12. Alonso, E. V., Cordero, M. S., De Torres, A. G. and Pavón, J. C. (2006). Lead ultra-trace on-line preconcentration and determination using selective solid phase extraction and electrothermal atomic absorption spectrometry: applications in seawaters and biological samples. Analytical and Bioanalytical Chemistry, 385: $1178-1185$. 
Thongsaw et al: SOLIDIFIED FLOATING ORGANIC DROP MICROEXTRACTION-

ELECTROTHERMAL ATOMIC ABSORPTION SPECTROMETRY FOR THE

DETERMINATION OF TRACE AMOUNTS OF LEAD IN WATER SAMPLES

13. Peker, D. S. K., Turkoglu, O. and Soylak, M. (2007). Dysprosium (III) hydroxide coprecipitation system for the separation and preconcentration of heavy metal contents of table salts and natural waters. Journal of Hazardous Materials, 143: 555 - 560 .

14. Luconi, M. O., Silva, M. F., Olsina, R. A. and Fernández, L. P. (2000). Cloud point extraction of lead in saliva via use of nonionic PONPE 7.5 without added chelating agents. Talanta, 51: $123-129$.

15. Chen, J., Xiao, S., Wu, X., Fang, K., and Liu, W. (2005). Determination of lead in water samples by graphite furnace atomic absorption spectrometry after cloud point extraction. Talanta, 67: $992-996$.

16. Purohit, R., and Devi, S. (1992). Determination of trace amounts of lead by chelating ion exchange and on-line preconcentration in flow-injection atomic absorption spectrometry. Analytica Chimica Acta, 259: 53 - 60 .

17. Liang, P., Liu, R. and Cao, J. (2008). Single drop microextraction combined with graphite furnace atomic absorption spectrometry for determination of lead in biological samples. Microchimica Acta, 160: 135 - 139.

18. Rasmussen, K. E. and Pedersen-Bjergaard, S. (2004). Developments in hollow fibre-based, liquid-phase microextraction. TrAC Trends in Analytical Chemistry, 23: $1-10$.

19. Farajzadeh, M. A., Bahram, M., Zorita, S., and Mehr, B. G. (2009). Optimization and application of homogeneous liquid-liquid extraction in preconcentration of copper (II) in a ternary solvent system. Journal of Hazardous Materials, 161: 1535 - 1543.

20. Kozani, R. R., Assadi, Y., Shemirani, F., Hosseini, M. R. M., and Jamali, M. R. (2007). Part-per-trillion determination of chlorobenzenes in water using dispersive liquid-liquid microextraction combined gas chromatography-electron capture detection. Talanta, 72: $387-393$.

21. Jain, R. and Singh, R. (2016). Applications of dispersive liquid-liquid micro-extraction in forensic toxicology. TrAC Trends in Analytical Chemistry, 75: 227 - 237.

22. Zanjani, M. R. K., Yamini, Y., Shariati, S. and Jönsson, J. Å. (2007). A new liquid-phase microextraction method based on solidification of floating organic drop. Analytica Chimica Acta, 585: 286 - 293.

23. Dadfarnia, S. and Shabani, A. M. H. (2010). Recent development in liquid phase microextraction for determination of trace level concentration of metals - A review. Analytica Chimica Acta, 658: 107 - 119.

24. Zhu, X., Zhu, X. and Wang, B. (2006). Determination of trace cadmium in water samples by graphite furnace atomic absorption spectrometry after cloud point extraction. Microchimica Acta, 154: 95 - 100.

25. Moghadam, M. R., Dadfarnia, S. and Shabani, A. M. H. (2011). Speciation and determination of ultra-trace amounts of chromium by solidified floating organic drop microextraction (SFODME) and graphite furnace atomic absorption spectrometry. Journal of Hazardous Materials, 186: 169 - 174.

26. Chen, J., Xiao, S., Wu, X., Fang, K. and Liu, W. (2005). Determination of lead in water samples by graphite furnace atomic absorption spectrometry after cloud point extraction. Talanta, 67: $992-996$.

27. Naseri, M. T., Hosseini, M. R. M., Assadi, Y. and Kiani, A. (2008). Rapid determination of lead in water samples by dispersive liquid-liquid microextraction coupled with electrothermal atomic absorption spectrometry. Talanta, 75: $56-62$. 